\title{
New Florida Foliage Plant Cultivar: 'Diamond Bay' Aglaonema1
}

\section{R.J. Henny, J. Chen, T.A. Mellich and M.S. Brennan²}

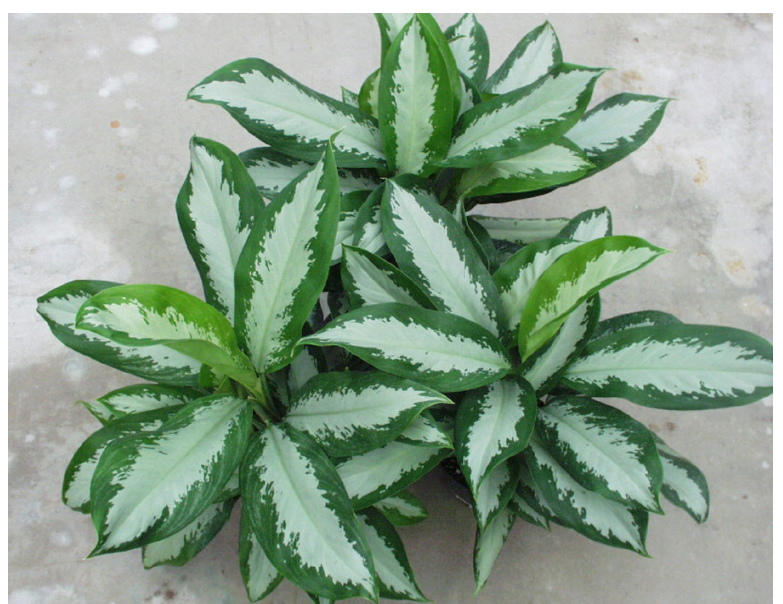

Figure 1. Mature Aglaonema 'Diamond Bay' plants grown for 9 months in 6 inch (1.6L) containers.

\section{Origin}

Aglaonema are indigenous to southeast Asia and comprise 21 species. They are members of the plant family Araceae, and are commonly called "Chinese evergreen." Historically, new Aglaonema cultivars were introduced directly from the wild and were largely variants of Aglaonema crispum, $A$. commutatum or A. modestum. Control of Aglaonema flowering (Henny; 1983) and development of pollination techniques (Henny; 1985) led to the production of many new cultivars in the past twenty years by both public and private breeders.

In 1992, Aglaonema 'Silver Bay' (Henny et al.; 1992) an interspecific hybrid, was developed and released by the Foliage Plant Breeding Program of the University of Florida at the Mid-Florida Research and Education Center (MREC) - Apopka. 'Silver Bay' remains a very popular cultivar because of its beautiful foliage, good growth habit and excellent performance in interior conditions.

Commercial tissue culture propagation was used to speed the release of Aglaonema 'Silver Bay' hybrids to foliage producers. Aglaonema 'Diamond Bay' is a mutant found among a population of tissue-cultured Aglaonema 'Silver Bay' plants.

The original Aglaonema 'Diamond Bay' mutant was noticed because it lacked one of the foliar variegation patterns normally present in 'Silver Bay' leaves and petioles. The 'Diamond Bay' selection was increased by stem cuttings at MREC-Apopka and

1. This document is ENH1073, one of a series of the Environmental Horticulture Department, Florida Cooperative Extension Service, Institute of Food and Agricultural Sciences, University of Florida. Original publication date October 23, 2007. Visit the EDIS Web Site at http://edis.ifas.ufl.edu.

2. Henny, R.J., Professor, Department of Environmental Horticulture; J. Chen, Associate Professor, Department of Environmental Horticulture; Terri Mellich and Mary Brennen, Biologists, University of Florida, Institute of Food and Agricultural Science, Mid-Florida Research and Education Center, 2725 Binion Road, Apopka, FL 32703

The use of trade names in this publication is solely for the purpose of providing specific information. UF/IFAS does not guarantee or warranty the products named, and references to them in this publication does not signify our approval to the exclusion of other products of suitable composition. 
observed for stability. Aglaonema 'Diamond Bay' selection remained stable while maintaining its new foliar pattern and other desirable traits of the parent. Therefore this cultivar has been selected for release.

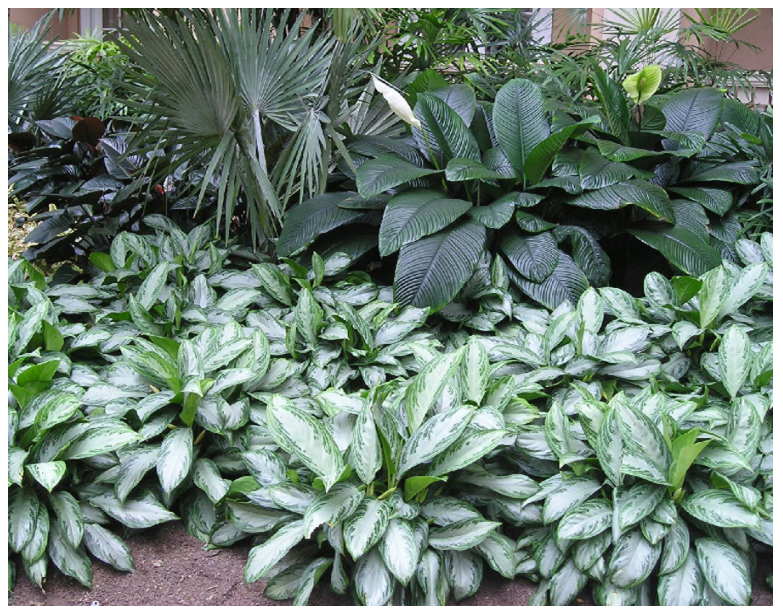

Figure 2. Aglaonema 'Silver Bay', the parent of Aglaonema 'Diamond Bay' performs well in commercial installations.

\section{Description}

Mature Aglaonema 'Diamond Bay' leaves are lance-shaped $10-12 \mathrm{~cm}(4-5 \mathrm{in})$ wide and $28-30 \mathrm{~cm}$ (11-12 in) long. Leaf margins are smooth (entire) and the leaf tissue (lamina) on either side of the midrib tends to be of slightly unequal widths, resulting in slight curving of the blade towards the narrower side. Leaves exhibit a central grey-green area that extends out from each side of the midrib to cover slightly more than half of the total leaf surface (Fig. 1). Leaf margins are green and meet the lighter grey-green colored central area along irregular borders. The undersides of the leaves are uniform green.

The outer petiole wings are yellow-green and blend into the petiole center, which is a lighter yellow-green. As it nears the leaf blade, the entire petiole color becomes uniform. The stem color blends from areas that are a darker yellow-green to lighter areas in the same color range. These colors are not normally visible due to the clasping habit of the petiole, which surrounds the stem.

\section{Performance}

Growth characteristics of Aglaonema 'Diamond Bay' were determined using 50 newly rooted stem cuttings with 4-5 leaves per cutting. Plants were potted into $1.6 \mathrm{~L}$ (6-inch) plastic pots containing VerGro Container Mix A (Verlite Co., Tampa, Fla. 33610). Plants were grown in a greenhouse under $70 \%$ shade, a temperature range of 59 to $93^{\circ} \mathrm{F}$ (15 to $34^{\circ} \mathrm{C}$ ) and on natural photoperiod. Ten plants were grown in a completely randomized design for 9 months from October 2000 until July 2001 at each of five fertilizer levels equivalent to a total of 1.4, 1.8, 2.2, 2.7 and $3.2 \mathrm{~g} \mathrm{~N}$ per pot. Fertilizer levels were derived from a 3:1:2 ratio of $\mathrm{N}: \mathrm{P}: \mathrm{K}$ applied as a liquid at $100 \mathrm{ml}$ per pot per week.

At the termination of the growth tests, canopy height and width, length and width of largest leaf, number of basal shoots and a visual quality rating where $1=$ poor; $3=$ acceptable (saleable) and $5=$ excellent quality were recorded.

Aglaonema 'Diamond Bay' reached marketable size in 9 months. Plants were well- branched, averaging approximately 3 basal shoots per plant. There were no significant differences in canopy height or width, leaf size or basal shoot number due to different fertilizer levels (Table 1). Visual quality showed a significant response to fertilizer level, but all plants were rated as excellent or near excellent in quality. There was a slight loss of quality at the lowest and at the highest nutritional levels.

These important tropical ornamental foliage plants can readily adapt to low light and low relative humidity levels encountered under interior conditions. Aglaonema 'Diamond Bay' does not require acclimatization prior to installation in interior environments.

\section{Availability}

Aglaonema 'Diamond Bay' is intended for commercial producers growing finished plants in 6-inch or 8-inch (1.6 or 3.9 L) containers. A patent application for this cultivar has been submitted to the United States Patent and Trademark Office and plant patent rights have been assigned to the Florida Foundation Seed Producers. Stock plants have been released to University of Florida licensed cooperating Florida tissue culture labs for propagation and distribution. Information about participating labs may be obtained by writing the Florida Foundation Seed Producers, Inc., P.O. Box 309, Greenwood, FL 
32443. Plants for research purposes may be obtained directly from the author.

\section{Literature Cited}

Henny, R.J. 1983. Flowering of Aglaonema commutatum 'Treubii' following treatment with gibberellic acid. HortScience 18:374.

Henny, R.J. 1985. In vivo pollen germination of Aglaonema affected by relative humidity. HortScience 20:142-143.

Henny, R.J., R.T. Poole and C.A. Conover. 1992. 'Silver Bay' Aglaonema. HortScience 27:1238. 
Table 1. Final canopy height and width, length and width of largest leaf, number of basal shoots and plant quality of Aglaonema 'Diamond Bay' grown from cuttings in 6-inch (1.6 L) pots with different rates of $\mathrm{N}$ for 9 months from October 2000 until July 2001.

\begin{tabular}{|c|c|c|c|c|c|c|}
\hline $\begin{array}{c}\text { N rate } \\
(\mathrm{g} \text { per pot })^{x}\end{array}$ & $\begin{array}{c}\text { Canopy } \\
\text { height }(\mathrm{cm})\end{array}$ & $\begin{array}{c}\text { Canopy } \\
\text { width }(\mathrm{cm})\end{array}$ & $\begin{array}{l}\text { Leaf length } \\
\qquad(\mathrm{cm})\end{array}$ & $\begin{array}{l}\text { Leaf } \\
\text { width } \\
\text { (cm) }\end{array}$ & $\begin{array}{c}\text { No. basal } \\
\text { shoots }\end{array}$ & $\begin{array}{c}\text { Plant } \\
\text { Qualityy }\end{array}$ \\
\hline \multicolumn{7}{|l|}{1.4} \\
\hline 1.8 & 33.5 & 55.7 & 29.6 & 11.4 & 3.0 & 4.6 \\
\hline 2.2 & 33.1 & 54.9 & 29.7 & 11.6 & 3.4 & 5.0 \\
\hline 2.7 & 35.4 & 54.7 & 29.3 & 11.4 & 3.4 & 5.0 \\
\hline 3.2 & 33.1 & 53.4 & 29.6 & 11.3 & 2.6 & 4.9 \\
\hline Significance $^{z}$ & 378 & 5450 & $3 P S^{1}$ & Nड़s & B.S & 488 \\
\hline
\end{tabular}

${ }^{\mathrm{x}}$ Total amount of $\mathrm{N}$ applied during the 9-month production period.

${ }^{y}$ Visual rating where 1 = poor, 3 = saleable and $5=$ excellent quality.

${ }^{\mathrm{z}} \mathrm{NS}=$ no significant differences; $\mathrm{S}$ = significant differences between treatments. 